\title{
The Influence Of Health Education With Audio Visual Media On Clean And Healthy Living Behavior (PHBS) In Grade III-V Students At Wanurojo Kemiri Purworejo State Elementary School
}

\author{
Eka Kurnia Astuti
}

Nursing Science Study Program, Aisyiyah College of Health Sciences Yogyakarta

\section{ARTICLEINFO}

Keywords:

Health education, audio-visual media, PHBS
E-mail:

ekakurnia09@gmail.com

\section{ABSTRACT}

Clean and Healthy Living Behaviors (PHBS) in children are very important so that good health education is needed. Health education with audio visual media will improve clean and healthy living behaviors because children can hear and see firsthand clean and healthy living behaviors that are good and correct. It is known the influence of health education with audio visual media on clean and healthy living behavior (PHBS) in grade III-V students at Wanurojo Kemiri Purworejo State Elementary School.

The design of this study uses pre experiment (one group pretest posttest). Respondents in this study numbered 45 students aged 8-11 years. Health education with audio visual media affects clean and healthy living behavior (PHBS) in grade III-V students at Wanurojo Kemiri Purworejo State Elementary School $(\mathrm{P}<0.01)$. Because health education with audio visual media is influential in improving clean and healthy living behaviors, health education with audio visual media can be utilized to improve clean and healthy living behaviors of elementary school children.

Copyright (C) 2020 Eduhot Journal.All rights reserved. is Licensed under a Creative Commons AttributionNonCommercial 4.0 International License (CC BY-NC

\section{INTRODUCTION}

According to Hidayat, children are unique individuals and have needs according to their stage of development[1]. As a unique individual, children have various needs that differ from one another according to the age of growth and development. These needs can include physiological, psychological, social and spiritual needs. In the stage of achieving growth and development, children can be grouped into two groups, namely the age group 0-6 years (prenatal and postnatal stages) and the age group 6 years and over divided into the school period (6-12 years).[2].

According to Freud, children aged 6-12 years are often called the middle or latent period, which is a period of calm and comfort. Boys often hang out with same-sex friends, as well as girls[3]. Therefore, this period is also known as natural homosexuality. During the school period, children's growth is faster than in the pre-school period. Skills and intellectuals are growing, love to play and group with friends of the same sex[4]

Understanding childhood is a period that will determine the quality of life when he grows up, we must pay attention to children's health because children at school age already know good relationships in the family, school and play environment so that at this age children are vulnerable to contracting a disease [5]. When self-care (PHBS) cannot be maintained, it will facilitate the occurrence of a disease and can even result in death [6]. The impacts of not practicing PHBS are

The Effect of Health Education Using Audio Visual Media on Clean and Healthy Living Behavior (PHBS) in Class III-V Students at SD Negeri Wanurojo Kemiri Purworejo, 
many, the first is the impact of not washing hands properly are diarrhea, ARI, worm infection, eye pain and skin disease. The second is the impact of not maintaining healthy hair, mouth and nails, namely dandruff on the head, split ends, lice and mold. In the mouth can occur cavities, toothache, tartar and bad breath. On the nails, the impact is that long and dirty nails will become a nesting place for various kinds of germs, such as worm eggs nesting in nails that are rarely cleaned. The worm eggs will also enter the body through food held with dirty hands [6]. And the third impact of not practicing PHBS is the impact of indiscriminate snacks, namely the presence of the Entamoeba histolytica virus. This virus infects the digestive tract through contaminated food and drink or from dirty hands. This parasitic infection can spread from the digestive tract to the bloodstream at an advanced stage[7]. This parasitic infection can cause dysentery to inflammation of the liver. Other impacts of the lack of PHBS implementation include an unsupportive learning atmosphere due to a dirty school environment, decreased enthusiasm and achievement in learning and teaching in schools, lowering the image of the school in the general public.[8].

Based on data from the World Health Organization or the World Health Organization, every year 100,000 Indonesian children die from diarrhea, while data from the Ministry of Health shows that among 1000 residents there are 300 people who contract diarrheal disease throughout the year. Meanwhile, there are still many data on diseases that often attack school-age children. But even so, to love glory, He is Most Beautiful, who loves beauty, so clean your places."

In the hadith it is explained that Allah SWT is holy who likes holy things, therefore as Muslims we should always maintain the sanctity, cleanliness of both ourselves and the environment.[9]. From this statement, clean and healthy living behavior is included in one of the important things to maintain cleanliness and beauty. Clean and healthy living behavior (PHBS) itself is a form of embodiment of a healthy paradigm in a healthy-oriented individual, family and community culture, aiming to improve, maintain and protect their physical, mental, spiritual and social health.[10]. In addition, the clean and healthy living behavior program aims to provide learning experiences or create conditions for individuals, groups, families, by opening lines of communication, information and education to increase knowledge, attitudes and behavior so that people are aware, willing and able to practice clean living behaviors. and healthy through a leadership approach (advocacy), building atmosphere (social support) and community empowerment (empowerment). Thus, the community can recognize and solve their own problems, especially in their respective settings (Depkes RI, 2002). "Prevention is better than cure" or in the English expression "prevention is better than cure", the right words of wisdom in improving health status. One of the efforts that can be done by nurses to improve health status is to conduct health education through effective methods which are expected to be able to apply PHBS habits to themselves and their families in a relatively long time. The benefits of clean and healthy living behavior (PHBS) in schools include the creation of clean and healthy schools so that students are protected from various disorders and threats of disease, increasing the spirit of the teaching and learning process, the image of the school as an educational institution is increasing so that it can attract the interest of parents (the community). ), increasing the image of local governments in the field of education (MOH, 2006).

For this reason, with regard to PHBS, Kepmenkes No. 852/Menkes/SK/XI/2008 explains the national strategy for community-based total sanitation which is stated in the statement that the government has paid attention to hygiene and sanitation by establishing open defecation free and improving clean living behavior. and healthy in 2009 in the National Medium Term Development Plan (RPJMN) 2004-2009. This is in line with the government's commitment to achieving the Millennium Development Goals (MDGs) in 2015. That is to increase access to drinking water and basic sanitation on an ongoing basis to half of the proportion of the population who do not have access. Furthermore, regarding the definition of health education is an effort or activity to create community behavior that is conducive to health. It means,[11]. The target of health education in Indonesia is based on Indonesia's development program, namely the general public with an orientation to rural communities. Communities in certain groups (women, youth, youth, groups of educational institutions from kindergarten to college, both private and public schools) and individual targets with individual health education techniques[12].

The Effect of Health Education Using Audio Visual Media on Clean and Healthy Living Behavior (PHBS) in Class III-V Students at SD Negeri Wanurojo Kemiri Purworejo, 


\section{METHOD}

The design of this study used a pre-experimental design (one group pretest posttest). This design does not have a comparison group (control), but at least the first observation (pretest) has been carried out which allows researchers to test the changes that occur after the experiment. The independent variable is health education with audio-visual media. The dependent variable is the clean and healthy behavior of students at SDN Wanurojo Kemiri Purworejo. Confounding Variables:

a. Education : Not controlled because the sample comes from the same school.

b. Information : Not controlled because the information provided is the same through audiovisual media about PHBS.

c. Culture : Not controlled because the students are from the same Javanese ethnicity and culture.

d. Age : Controlled by taking samples aged between 9-11 years.

e. Experience : Not controlled because the students have the same experience and come from the same school.

f. Interest : Controlled by taking samples of elementary school-aged children in grades III-V and randomly selected.

g. Work : It is not controlled because the work of the parents of students is mostly the same, namely farmers.

Health education with audio-visual media about clean and healthy living behavior is the delivery of information to respondents about PHBS as an indicator of school management including washing hands with running water and using soap, eating healthy snacks in the school canteen, using clean and healthy latrines.

The population in this study were elementary school age children at SDN Wanurojo Kemiri Purworejo class III-V, totaling 45 students. Sampling in this study was carried out by probability sampling method using simple random sampling technique, namely by taking samples from the population at random without regard to the existing strata in the population. In this study, the researcher used the sample formula developed by Isaac and Michael. From the sample formula, the researchers obtained the number of research samples, namely 42 children from a population of 45 children who will be taken randomly. For a minimum sample of 42 but during the study all the population will be taken because the total population is only 45 children. In addition, respondents in this study must meet the following inclusion criteria:

a. Elementary school students grade III-V.

b. Students can read and write.

c. Students are present at the time of data collection.

d. Students are willing to be research respondents.

The data collection tools used are:

a. A list of questions about the identity of the respondent.

b. Instruments for data collection using a questionnaire, namely with a number of written questions that are used to obtain information from respondents. Where respondents only put a sign $(\sqrt{ })$ in the appropriate column.

c. For health education about PHBS using audio-visual media with educational materials including correct PHBS methods (cutting nails, brushing teeth, shampooing, washing hands and feet, bathing with soap, cleaning with clean water after defecating and urinating, dressing clean and neatly) and consequences if you don't have PHBS.

Data collection techniques and the course of research are carried out by:

a. Choose who will be the sample.

b. Then the researchers collected data by providing identity sheets and making observations for initial measurements of children's behavior one day before health education was conducted.

c. The next day, the students were given a pretest about clean and healthy living behavior.

d. Respondents who will be doing research get treatment (health education about PHBS with audio-visual media).

e. Providing health education about PHBS with audio-visual media for 40 minutes.

The Effect of Health Education Using Audio Visual Media on Clean and Healthy Living Behavior (PHBS) in Class III-V Students at SD Negeri Wanurojo Kemiri Purworejo, 
f. On the next day, respondents were given a questionnaire sheet for evaluation or posttest about PHBS.

\section{RESULTS AND DISCUSSION}

\subsection{Results}

There are 14 workers at SD Negeri Wanurojo, consisting of 1 principal, 6 class teachers, 1 religion teacher, 1 sports teacher, 1 English teacher, 1 school custodian and 3 assistant teachers. Wanurojo State Elementary School has 11 rooms, consisting of 1 principal's room, 1 teacher's room, 6 classrooms, 1 UKS room, 1 library room and 1 prayer room. The number of students at SD Negeri Wanurojo this year is 96 students with 30 boys and 66 girls divided into 6 classes, namely class I totaling 18 students, class II totaling 16 students, class III totaling 16 students, class IV totaling 14 students, class V totaling 15 students, class VI totaling 17 students. Characteristics of respondents observed in this study include the age of the child,

Characteristics of students about clean and healthy living behavior based on age. Age is the length of a person's life since birth. Characteristics of students by age as follows:

Table. 1 Frequency Distribution of Respondents Age

\begin{tabular}{ccc} 
Age & Frequency & Percent $\mathbf{( \% )}$ \\
\hline 8 years & 2 & 4.4 \\
9 years & 19 & 42.2 \\
10 years & 15 & 33.3 \\
11 years old & 9 & 20.0 \\
\hline Total & 45 & 100.0
\end{tabular}

From the data above, the majority of respondents are 9 years old, as many as 19 people $(42.2 \%)$. While the respondents aged 8 years are 2 people $(4.4 \%)$.

Characteristics of students about clean and healthy living behavior based on gender are as follows:

Table. 2 Frequency Distribution of Respondents Gender

\begin{tabular}{lll} 
Gender & Frequency & Percent (\%) \\
\hline Man & 20 & 44.4 \\
Woman & 25 & 55.6 \\
\hline Total & 45 & 100.0
\end{tabular}

Based on the table above, gender in this study was mostly dominated by women, namely $55.6 \%$ while men were $44.4 \%$.

Characteristics of students about clean and healthy living behavior based on grade level are as follows:

\begin{tabular}{ccc}
$\begin{array}{c}\text { Table. } 3 \\
\text { Class }\end{array}$ & $\begin{array}{c}\text { Distribution of Number of Students by Class } \\
\text { Frequency }\end{array}$ & \begin{tabular}{c} 
Percent (\%) \\
\hline III
\end{tabular} \\
IV & 16 & 35.6 \\
V & 14 & 31.1 \\
\hline Total & 15 & 33.3 \\
\hline
\end{tabular}

Based on the table above, the highest number of students based on class is class III, which is $35.6 \%$, and the least is class IV, which is $31.1 \%$.

The research data on the variables of clean and healthy living behavior used a knowledge questionnaire. The results of respondents' answers to the statements presented in the variables can be explained as follows:

The results of the respondent's questionnaire answers to student behavior regarding clean and healthy living behavior need to be categorized, to determine the level of each respondent's level of knowledge. Student behavior about clean and healthy living behavior consists of behavioral pretest and behavioral posttest groups. For more details, see the summary table below:

Table. 4 Distribution of Clean and Healthy Behavior (PHBS) Variables

The Effect of Health Education Using Audio Visual Media on Clean and Healthy Living Behavior (PHBS) in Class III-V Students at SD Negeri Wanurojo Kemiri Purworejo, 


\begin{tabular}{ccccc} 
Variable & Mak & Min & mean & Std. Deviation \\
\hline Pretest Behavior & 84 & 56 & 70.58 & 5,778 \\
Posttest Behavior & 84 & 72 & 79.47 & 3,057
\end{tabular}

Based on data analysis, it is shown that the pretest of clean and healthy living behavior has the highest score of 84 , the lowest score of 56, the average value of 70.58 and the standard deviation of 5.778. The students' posttest on clean and healthy living behavior had the highest score of 84 , the lowest score of 72, the average value of 79.47 and the standard deviation of 3.057. Based on the table below, it can be seen that there was an increase in behavior in SDN Wanurojo Kemiri Purworejo students after being given health education with audio-visual media, namely an increase in scores on the posttest. For example, at the pretest, there were 18 students who always changed socks every 2 days and at the posttest, there were 35 students. The second example was during the pretest, there were 22 students who always washed their hands using running water and at the posttest, there were 29 students.

Table. 5 Pretest and posttest Clean and Healthy Behavior

Score PHBS

\begin{tabular}{|c|c|c|c|c|c|c|c|c|c|}
\hline \multirow[t]{2}{*}{ No } & \multirow[t]{2}{*}{ Statement } & \multicolumn{4}{|c|}{ Pretest } & \multicolumn{4}{|c|}{ Posttest } \\
\hline & & $\mathrm{S}$ & SR & $\mathrm{KD}$ & $\mathrm{TP}$ & $\mathrm{S}$ & SR & $\mathrm{KD}$ & $\mathrm{TP}$ \\
\hline 1. & I shower 2 times a day with bath soap & 40 & 5 & - & - & 42 & 3 & - & - \\
\hline 2. & $\begin{array}{l}\text { I take a shower using clean water every } \\
\text { day }\end{array}$ & 41 & 4 & - & - & 38 & 7 & - & - \\
\hline 3. & $\begin{array}{l}\text { After I take a shower, my body feels } \\
\text { fresh }\end{array}$ & 38 & 5 & 2 & - & 39 & 6 & - & - \\
\hline 4. & I change my toothbrush every 2 months & 12 & 13 & 13 & 7 & 14 & 24 & 5 & - \\
\hline 5. & I brush my teeth 2 times a day & 34 & 7 & 4 & - & 38 & 7 & - & - \\
\hline 6. & I brush my teeth before eating & 8 & 13 & 16 & 8 & - & - & 10 & 35 \\
\hline 7. & $\begin{array}{l}\text { I didn't have my teeth checked every } 6 \\
\text { months to the health center or dentist }\end{array}$ & 3 & 14 & 5 & 23 & 30 & 15 & - & - \\
\hline 8. & I change socks every 2 days & 18 & 10 & 11 & 6 & 35 & 9 & 1 & - \\
\hline 9. & I wear school uniform no neat & 13 & 3 & 1 & 28 & - & - & 13 & 37 \\
\hline & $\begin{array}{l}\text { I go to school wearing uniform not on } \\
\text { schedule }\end{array}$ & - & 1 & 3 & 41 & - & - & 3 & 42 \\
\hline 11. & I wash my hands using flowing water & 22 & 13 & 8 & 1 & 29 & 16 & - & - \\
\hline & $\begin{array}{l}\text { I wash my hands with soap before and } \\
\text { after eating }\end{array}$ & 29 & 12 & 3 & 1 & 32 & 13 & - & - \\
\hline 13. & I cut my nails once a week & 19 & 16 & 7 & 3 & 25 & 20 & - & - \\
\hline & $\begin{array}{l}\text { I wash my hands but I don't rubbing } \\
\text { between fingers and nails. }\end{array}$ & 1 & 6 & 21 & 17 & - & - & 15 & 30 \\
\hline & $\begin{array}{l}\text { I pee (pee) in the bathroom/WC every } \\
\text { day }\end{array}$ & 26 & 3 & 15 & 1 & 28 & 17 & - & - \\
\hline & $\begin{array}{l}\text { I do not wash with clean water after } \\
\text { defecating and urinating (peeing) }\end{array}$ & 9 & 7 & 3 & 26 & - & - & 15 & 35 \\
\hline 17. & When I go to school I wear shoes & 39 & 5 & - & 1 & 42 & 3 & - & - \\
\hline 18. & I don't wash my feet after played & 5 & 4 & 19 & 17 & - & - & 2 & 43 \\
\hline & $\begin{array}{l}\text { I wash my hair or shampoo with } \\
\text { shampoo every } 2 \text { days }\end{array}$ & 18 & 14 & 13 & - & 31 & 14 & - & - \\
\hline & $\begin{array}{l}\text { I comb my hair after every shower and } \\
\text { before leaving school }\end{array}$ & 33 & 7 & 5 & - & 38 & 6 & 1 & - \\
\hline 21 & My hair is dirty, lice and smelly & - & 1 & 9 & 35 & - & - & 2 & 43 \\
\hline
\end{tabular}

The Effect of Health Education Using Audio Visual Media on Clean and Healthy Living Behavior (PHBS) in Class III-V Students at SD Negeri Wanurojo Kemiri Purworejo, 
Table. 6 Category Outcomes of Students' Clean and Healthy Behavior at Pretest and Posttest

\begin{tabular}{|c|c|c|c|c|}
\hline \multirow{2}{*}{ PHBS Students } & \multicolumn{2}{|c|}{ Pretest } & \multicolumn{2}{|c|}{ Posttest } \\
\hline & & Percentage & freq & Percentage \\
\hline Very good & 37 & $82.2 \%$ & 45 & $100 \%$ \\
\hline Well & 8 & $17.8 \%$ & 0 & $0 \%$ \\
\hline Amount & 45 & $100 \%$ & 45 & $100 \%$ \\
\hline
\end{tabular}

Based on the table above, it shows that students' clean and healthy living behavior has increased. At the pretest the very good category was only $82.2 \%$, at the posttest the very good category became $100 \%$. The results of the pretest were very different from the results of the preliminary study because without the knowledge of the researcher, before the researcher intervened the students had received counseling from the local health center 2 times and the village midwife once about maintaining personal hygiene.

Before analyzing the research data obtained using the t-test, it is necessary to first test the prerequisites for data analysis. The prerequisite that must be met is the normality test of the data. The results are presented as follows:

The normality test was tested on each research variable, namely satisfaction and expectation. The normality test was carried out using a computer with the saphiro wilk test program. The data is normally distributed if the calculated significance level value is greater than the 0.05 significance level value. The results of the data normality test using the Shapiro Wilk test for each research variable are presented as follows:

Table. 7 Data Normality Test Results

\begin{tabular}{ccccc}
\hline Variable & Statistics & df & Signification & Note: \\
\hline Pretest Behavior & 0.984 & 45 & 0.784 & Normal \\
Posttest Behavior & 0.948 & 45 & 0.043 & Abnormal \\
\hline
\end{tabular}

From the table above, it can be seen that the significance value in the pretest data was 0.784 and the posttest data obtained a significance value of 0.043 . From the results of the normality test of the data above, it can be seen that only the pretest was normally distributed, while the posttest was not normally distributed. So if after the normality test the data is not normally distributed, the analysis uses the Wilxocon non-parametric statistical test. Wilcoxon Test The Effect of Health Education with Audio Visual Media on Clean and Healthy Behavior of Class III-V Students at SDN Wanurojo Kemiri Purworejo. The hypothesis in this study reads that there is an effect of health education with audio-visual media on the clean and healthy behavior of school-age children at SD Negeri Wanurojo Kemiri Purworejo.

The presence or absence of the influence of health education on the clean and healthy behavior of school-age children at SD Negeri Wanurojo Kemiri Purworejo will be analyzed using the nonparametric Wilcoxon test. The summary of the results is as follows:

Table. 8 Wilxocon Test Results Against PHBS

\begin{tabular}{|c|c|c|c|c|c|}
\hline Variable & & $\mathbf{N}$ & Mean Rank & Sum of Rank & Sign \\
\hline Pretest & negativeRank & $3^{\mathrm{a}}$ & 6.00 & 18.00 & 0.000 \\
\hline \multirow[t]{3}{*}{ Posttest } & Positive Rank & $42 b$ & 24.21 & 1017.00 & (Significant) \\
\hline & Ties & $0^{\mathrm{c}}$ & & & \\
\hline & Total & 45 & & & \\
\hline
\end{tabular}

Information :

$3 \mathrm{a}=$ posttest behavior $<$ pretest behavior $42 \mathrm{~b}=$ Posttest behavior $>$ pretest behavior $0 \mathrm{c}=$ Posttest behavior $=$ pretest behavior

From the table above, it can be seen that 42 respondents had a posttest behavior better than the pretest, 3 respondents had a posttest behavior less than the pretest and 0 respondents had the same posttest score as the pretest. The significance value on the Wilcoxon test shows 0.000 . This means

The Effect of Health Education Using Audio Visual Media on Clean and Healthy Living Behavior (PHBS) in Class III-V Students at SD Negeri Wanurojo Kemiri Purworejo, 
that the significance value is less than 0.05 so that the hypothesis in this study is accepted. This means that there is an effect of health education with audio-visual media on the clean and healthy behavior of school-age children at SD Negeri Wanurojo Kemiri Purworejo.

The results obtained using the PHBS questionnaire (checklist) consist of 21 statement items with answer choices of S (always), SR (often), KD (sometimes) and TP (never) and the average respondent answered most of the statements. appropriately. The results of pretest data collection showed that the behavior of clean and healthy living in the good category was $17.8 \%$, in the very good category $84.2 \%$ and in the poor category $0 \%$. This is different from the results of the preliminary study that the researcher did because without the knowledge of the researcher before being given treatment and intervention by the researcher, the respondents have received treatment from other parties 3 times so that there may be answers that do not match student behavior but students already know what correct and good behavior is so that the results can reach $84.2 \%$ very well. The number was obtained from a total of 45 students, namely $44.4 \%$ male students and $55.6 \%$ female students, consisting of $35.6 \%$ in class III, $31.1 \%$ in class IV and $33.3 \%$ in class V. respondents are the youngest 8 years as much as $4.4 \%$ and the oldest 11 years as much as $20.0 \%$. Health education with audiovisual media about clean and healthy living behavior has given positive changes to student behavior. because with audio-visual media has many benefits that are very helpful in providing information to students, can help students in understanding a material or science, students will concentrate more and have implications for their own understanding because hearing and vision devices are used simultaneously so that students concentrate more. In addition, elementary school children's thinking power already refers to things that are concrete and rational. According to Piaget, this period is known as the concrete operation period, the period when imaginary thinking ends and real thinking begins. This is evidenced by the clean and healthy behavior of students getting better after receiving health education with audio-visual media than before, for that it is expected that students can maintain and improve their clean and healthy living behavior. According to Atikah \& Eni (2012), that clean and healthy living behavior (PHBS) is a collection of behaviors that are practiced on the basis of awareness as a result of learning that enables children to help themselves in the health sector and play an active role in realizing public health. For this reason, it is necessary to have a clean and healthy lifestyle starting as early as possible. Because there are so many impacts of not having clean and healthy living behavior for students, including diarrhea, intestinal worms, skin diseases, toothaches, lice, an unsupportive learning atmosphere due to a dirty school environment, decreased enthusiasm and achievement in learning and teaching in schools. .

There are many factors that play a role in the formation of clean and healthy living behavior, including knowledge/education, beliefs, attitudes, culture and important people as guidelines/references. Another person who is considered important and senior in health education is someone who is competent in the field of health who has the appropriate educational background and has sufficient experience so that people/students who are given health education have more confidence in the information obtained. Accurately obtained information can increase a person's level of knowledge so that it can influence the behavior that will be formed by students (Notoatmodjo 2007). As for the results of the study using the same questionnaire, namely 21 statement items in 4 answer choices after receiving health education treatment with audio-visual media or watching videos of clean and healthy living behavior of all students in the very good category, namely $100 \%$. Research on clean and healthy living behavior has been conducted by Cahyani (2010). From the results of the study, it is known that there is an effect of health promotion on PHBS as indicated by the results of independent $t$-test analysis with $p$ value $=0.000(p$ 0.05) for attitude and $p=0.005(p 0.05)$ for PHBS. Based on the statistical results obtained from the Wilxocon test results for clean and healthy living behavior shows 0.000 . This means that the significance value is smaller than 0.05 so that the hypothesis in this study is accepted. Which means that there is an effect of health education with audio-visual media on clean and healthy living behavior (PHBS) in grade III-V students at SDN Wanurojo Kemiri Purworejo. Conceptually, it can be formulated that health education is an effort to influence other people, both individuals, groups and communities to carry out clean and healthy living behaviors. While operationally that health education is an activity that provides or improves their own

\section{The Effect of Health Education Using Audio Visual Media on Clean and Healthy Living Behavior} (PHBS) in Class III-V Students at SD Negeri Wanurojo Kemiri Purworejo, 
health (Notoatmojo, 2003). Health education conducted by researchers using the audio-visual method in one meeting for 40 minutes of PHBS video playback and evaluation of respondents was carried out on the next 3 days.

Providing information about health, especially clean and healthy living behavior with audiovisual media is a learning process to develop correct understanding and positive behavior towards health and after being given health education, respondents can do what is recommended and exemplified in the health education. Because the health education provided by researchers with audiovisual media, students will be able to see live broadcasts of what clean and healthy living behavior looks like and its impact. This is in accordance with the Wilxocon test with a significance value of 0.000 which indicates a significant difference, where before being given health education in the good category $17.8 \%$, very good $82.2 \%$. Meanwhile, after being given health education, the category was very good, $100 \%$. Health education is an effort to increase students' knowledge about clean and healthy living behavior which cannot be separated from research supporting factors. Research supporting factors include supporting facilities and infrastructure such as screens and LCDs to play PHBS videos, sufficient space, cooperative students and the presence of research assistants. The existence of supporting facilities can attract respondents to pay attention so that respondents are more cooperative towards the health education provided. The availability of lcd and screen is very helpful for PHBS video playback and the students pay attention enthusiastically. Researchers were also accompanied by research assistants to help make health education run smoothly with audio-visual media. The role of the assistant here is to help prepare health education by playing videos,

Before health education was conducted on hand washing, there were 8 students who had knowledge of hand washing behavior in the medium category and 1 student in poor category. After being given health education about hand washing, there was 1 student whose knowledge of hand washing behavior was in the medium category and none of the students had bad hand washing behavior knowledge category. Prior to health promotion using impure audio-visual media, the results in both groups were $\mathrm{p}>0.05$, $\mathrm{t}$-count $0.180<\mathrm{t}$-table 1.645 . Meanwhile, after health promotion was carried out with impure audio-visual media, the results in both groups were $p$ value $=0.000(p<0.05)$ and $t$ value $>t$ table.

This study was conducted to determine the effect of health education with audio-visual media on students' clean and healthy living behavior. Based on the statistical results obtained from the Wilxocon test results for clean and healthy living behavior shows 0.000 . This means that the significance value is smaller than 0.05 so that the hypothesis in this study is accepted. Which means that there is an effect of health education with audio-visual media on clean and healthy living behavior (PHBS) in grade III-V students at SDN Wanurojo Kemiri Purworejo.

\subsection{Discussion}

Based on the results of research that has been carried out at SDN 30 Kubu Dalam Padang City, it shows that more than half of the respondents have a normal body mass index classification, namely 68 respondents $(61.8 \%)$. A small proportion of respondents have a body mass index classification of obesity as many as 18 respondents (16.4\%). The results of this study are in line with research conducted by Khodijah,et.al, in 2013 that a small proportion of adolescents are included in the classification of the Body Mass Index of obesity, which is $4.95 \%$. In a study conducted by Khodaverdi,et.al,(2011) also found a small proportion of respondents with obesity body mass index calcification $(14,6 \%)$. Based on the decision of the Ministry of Health in 2010 children are said to be obese if they have a threshold of more than 2 elementary schools. Measurement of Body Mass Index of children is different from the measurement of Body Mass Index of adults. Measurement of Body Mass Index in children is interpreted according to the sex and age of the children.

Obesity in children is the result of calorie intake (energy) that exceeds the number of calories released or burned through metabolic processes in the body. Body Mass Index measurement is done by dividing the value of body weight $(\mathrm{kg})$ by the square of height $(\mathrm{m}) 2$, then adjusted to the 2010 Ministry of Health regulations for the categorization of Body Mass Index. Based on the researcher's analysis, the incidence of obesity mostly occurs in children aged 9 years, as many as 7 respondents

The Effect of Health Education Using Audio Visual Media on Clean and Healthy Living Behavior (PHBS) in Class III-V Students at SD Negeri Wanurojo Kemiri Purworejo, 
(6.36\%). Of the 13 children with obesity, 7 of them are male. The percentage of obesity incidence in SDN 30 Kubu Dalam Padang City (11.8\%) is greater than the incidence of obesity in West Sumatra in 2013 which is $7.7 \%$. For this reason, it is very necessary to take action to prevent the increasing incidence of obesity in school-age children.

Based on the results of research at SDN 30 Kubu Dalam Padang City in 2017 it shows that the majority of respondents have a good quality of life, namely 75 respondents $(68.2 \%)$ and the rest of respondents have a poor quality of life, namely 35 respondents $(31.8 \%)$. Quality of life in children is a feeling of comfort or health in children that describes multidimensional health and functional components such as physical, emotional, social and behavioral perceptions of the child or himself or his parents.

Quality of life in children consists of four components including dimensions, namely the child's ability to carry out daily activities such as walking, running, exercising, and also about physical health, namely energy, pain experienced, pain that interferes with activities. The emotional dimension assesses the child's ability to express anger, sadness, fear, sleep disturbances, and anxiety with what will happen to him. The social dimension assesses the child's ability to interact with peers and the child's ability to socialize at school. The dimensions of the school environment are the child's ability to focus when studying and doing school assignments, not attending school because of illness or going to the hospital.

Based on the results of research conducted on school-age children at SDN 30 Kubu Dalam, as many as 75 respondents have a good quality of life, almost never experience problems in any dimension of their quality of life. Meanwhile, of the 35 respondents who have a poor quality of life, the majority have problems in every dimension of their quality of life. Based on the results of research that has been carried out from $68.2 \%$ of respondents who have a good quality of life, almost half of the respondents have female sex, namely 49 respondents $(72.1 \%)$. Meanwhile, out of $31.8 \%$ of respondents who have a poor quality of life, a few of them or as many as 16 respondents have male sex. Based on the results of research that has been done from 75 respondents who have a good quality of life, as many as 29 respondents (38.7\%) aged 10 years. Meanwhile, of the 35 respondents who have a poor quality of life, $46.4 \%$ of them are children aged 9 years. Based on the results of research that has been carried out from 75 respondents who have a good quality of life, as many as 72 respondents stated that they never found it difficult to walk more than 100 meters, as many as 62 respondents stated that they had never had difficulty running, as many as 74 respondents stated that they had never experienced difficulty running. difficulty to bathe independently, as many as 69 respondents stated that they never had difficulty doing their daily work. In addition, there were 71 respondents who stated that they never had difficulty getting along with other friends.

Based on the results of research that has been carried out at SDN 30 Kubu Dalam Padang City, of 35 respondents who have a poor quality of life, 15 of them stated that they always felt difficult when running, as many as 14 of them stated that they always found it difficult to do activities and exercise, as many as 15 respondents stated that they always felt sick and sore, as many as 23 respondents said they always felt angry, as many as 17 respondents said they always felt that other children did not want to be friends with themselves, and as many as 8 respondents said they always had difficulty doing homework at home. Based on the results of research conducted at SDN $30 \mathrm{Kubu}$ Dalam, it was found that the best quality of life was found in the social dimension, as many as 79 respondents $(71.8 \%)$, while the poor quality of life is mostly found in the emotional dimension, as many as 40 respondents $(36.4 \%)$. Based on the results of this study, the quality of life of school-age children at SDN $30 \mathrm{Kubu}$ Dalam in terms of physical dimensions, there are as many as 74 respondents $(67.3 \%)$ have a good quality of life, while $36(32.7 \%)$ respondents have a poor quality of life. A total of 73 children who have a good quality of life stated that they never had difficulty taking a bath on their own. Meanwhile, of the 36 respondents who had a poor quality of life, 15 of them stated that they always had difficulty running and the other 13 respondents stated that they often had difficulty running. there are as many as 74 respondents $(67.3 \%)$ have a good quality of life, while $36(32.7 \%)$ respondents have a poor quality of life. A total of 73 children who have a good quality of life stated that they never had difficulty taking a bath on their own. Meanwhile, of the 36 respondents who had a

The Effect of Health Education Using Audio Visual Media on Clean and Healthy Living Behavior (PHBS) in Class III-V Students at SD Negeri Wanurojo Kemiri Purworejo, 
poor quality of life, 15 of them stated that they always had difficulty running and the other 13 respondents stated that they often had difficulty running. there are as many as 74 respondents $(67.3 \%)$ have a good quality of life, while $36(32.7 \%)$ respondents have a poor quality of life. A total of 73 children who have a good quality of life stated that they never had difficulty taking a bath on their own. Meanwhile, of the 36 respondents who had a poor quality of life, 15 of them stated that they always had difficulty running and the other 13 respondents stated that they often had difficulty running.

In the emotional dimension, 70 respondents $(63.6 \%)$ had a good quality of life, and another 40 respondents (36.4\%) had a poor quality of life. Of the 70 respondents who had a good quality of life, 47 of them stated that they never felt angry, while of the 40 respondents who had a poor quality of life, 14 of them stated that they often felt sad. In the social dimension, 79 respondents $(71.8 \%)$ had a good quality of life, and 31 respondents $(28.2 \%)$ had a poor quality of life. In this dimension, 74 respondents stated that they never had difficulty getting along with other friends.

Based on the results of research on the relationship between the incidence of obesity and the quality of life of school-age children at SDN 30 Kubu Dalam Padang City in 2017, it was found that 75 respondents $(94.9 \%)$ with a lean and normal body mass index classification had a good quality of life. A total of 31 respondents with a body mass index classification of fat and obesity have a poor quality of life. The results of statistical tests obtained $p$ value $=0.000$ which means that there is a significant relationship between the incidence of obesity and the quality of life of school-age children. Based on the results of this study obtained from 75 respondents $(94.9 \%)$ of respondents who have a good quality of life, as many as 72 respondents of whom stated that they never had difficulty walking more than 100 meters,

Based on the results of this study, it was also found that 31 respondents with a body mass index classification of fat and obesity had poor quality of life, as many as 14 of them stated that they always had difficulty doing activities and exercising, as many as 15 of them stated that they always had difficulty running, as many as 23 respondents stated that they always feel angry, as many as 6 respondents stated that they always felt that their other friends did not want to be friends with themselves and as many as 8 respondents stated that they always found it difficult to do homework.

\section{CONLUSION}

Efforts are needed to improve health education with audio-visual media regarding the PHBS implementation program for all elementary school students. It is recommended to all educators (teachers) to always teach their students PHBS health education with easy-to-understand audio-visual media so that children can better understand the importance of PHBS for everyday life. It is recommended to the local health center to carry out a health education program with audio-visual media about clean and healthy living behavior (PHBS) in the elementary school on a scheduled and routine basis, not just a schedule, so that the students' clean and healthy living behavior is better and the health status of the students is better. students in particular increased. Adding discourse for readers or students in the library about scientific information about the importance of methods in PHBS health education with audio-visual media and providing concrete video examples about PHBS. Provide wider opportunities to develop health education not only with audio-visual media. It is expected to use this method and add other methods that will attract students' interest when given health education. It is hoped that during the preliminary study without the knowledge of the respondent so that the results obtained between the preliminary study and the results of the research are synchronized. It is expected that the data collected will be accompanied by direct interviews and direct observations without the knowledge of the students.

Based on the results of research and discussion conducted by researchers, it can be concluded:

- Analysis of the results of the student questionnaire pretest, namely $82.2 \%$ very good behavior and $17.8 \%$ good behavior from a total of 45 students or $100 \%$. And in the Wilcoxon formula it is found that posttest $<$ pretest.

- Analysis of the results of the posttest student questionnaire obtained $100 \%$ clean and healthy life behavior is very good. And in the Wilcoxon formula it was found that $\mathrm{P}<0.05$ (significant value

The Effect of Health Education Using Audio Visual Media on Clean and Healthy Living Behavior (PHBS) in Class III-V Students at SD Negeri Wanurojo Kemiri Purworejo, 
0.000). So from the $\mathrm{p}$ value, it can be concluded that there is an effect of health education given by researchers on grade III-V students at SDN Wanurojo Kemiri Purworejo.

\section{REFERENCES}

[1] S. R. Talango, "KONSEP PERKEMBANGAN ANAK USIA DINI," Early Child. Islam. Educ. J., vol. 1, no. 1, 2020, doi: 10.54045/ecie.vli1.35.

[2] A. Wardani and Y. Ayriza, "Analisis Kendala Orang Tua dalam Mendampingi Anak Belajar di Rumah Pada Masa Pandemi Covid-19," J. Obs. J. Pendidik. Anak Usia Dini, vol. 5, no. 1, 2020, doi: 10.31004/obsesi.v5i1.705.

[3] M. Silviliyana, "Potret Pendidikan Indonesia Statistik Pendidikan 2019," Badan Pusat Statistik, 2019.

[4] D. Serdar, "PENINGKATAN KEMAMPUAN MOTORIK KASAR ANAK USIA 5-6 TAHUN MELALUI PERMAINAN LOMPAT TALI DI PAUD AL-IKHLAS TANGERANG SELATAN," Sustain., vol. 11, no. 1, 2019.

[5] A. Y. Zukmadani, B. Karyadi, and Kasrina, "Edukasi Perilaku Hidup Bersih dan Sehat (PHBS) dalam Pencegahan COVID-19 Kepada Anak-Anak di Panti Asuhan," J. Pengabdi. Masy., vol. 3, no. 1, 2020, doi: 10.29303/jpmpi.v3i1.440.

[6] T. N. dan S. Rosidah, "PENGARUH PENDIDIKAN KESEHATAN DENGAN MEDIA AUDIO VISUAL TERHADAP PENGETAHUAN CUCI TANGAN PAKAI SABUN PADA ANAK SD KELAS 2," J. Kesehat., vol. VIII, no. 1, 2020.

[7] D. A. Andriani, "PENGARUH PENDIDIKAN KESEHATAN DENGAN MEDIA AUDIO VISUAL TERHADAP PENGETAHUAN DAN SIKAP ANAK USIA SEKOLAH TENTANG PENYAKIT DEMAM BERDARAH," J. Med. (Media Inf. Kesehatan), vol. 7, no. 1, 2020, doi: 10.36743/medikes.v7i1.203.

[8] R. T. R. Lestari, I. G. A. S. Laksmi, and S. N. N. Sintari, "PENGARUH PENDIDIKAN KESEHATAN DENGAN MEDIA AUDIO VISUAL TERHADAP PENGETAHUAN REMAJA PUTRI TENTANG PEMERIKSAAN PAYUDARA SENDIRI (SADARI)," Bali Med. J., vol. 6, no. 1, 2019, doi: 10.36376/bmj.v6i1.66.

[9] L. M. Rahayuningrum, M. P. Gustomi, D. S. Wahyuni, and Y. D. A. Aziza, "Bermain game edukasi Islami dapat menurunkan kecemasan anak usia 6-12 tahun pada waktu sirkumsisi," Journals Ners Community, vol. 11, no. 1, 2020.

[10] Kemensos RI, "Perilaku hidup bersih dan sehat (phbs) penguatan kapabilitas anak dan keluarga," Penguatan Kapabilitas Anak dan Kel., 2020.

[11] A. Y. Damayanti, "Perilaku hidup bersih dan sehat (PHBS) dan status gizi remaja di pondok pesantren," Darussalam Nutr. J., vol. 4, no. 2, 2020, doi: 10.21111/dnj.v4i2.4850.

[12] N. Bur and S. Septiyanti, "Perilaku Hidup Bersih Dan Sehat (PHBS) Di SD Inpres Katangka Gowa," Celeb. Abdimas J. Pengabdi. Kpd. Masy., vol. 2, no. 1, 2020, doi: 10.37541/celebesabdimas.v2i1.301.

The Effect of Health Education Using Audio Visual Media on Clean and Healthy Living Behavior (PHBS) in Class III-V Students at SD Negeri Wanurojo Kemiri Purworejo, 